
2
E
M
I I A
R
R 0
O M

セミナー室

植物のゲノム編集一新技術開発と社会実装に向けた取り組み一-6

\title{
CRISPR/Cas9によるゲノム編集技術の進展と作物への応用 発展し続けるCRISPR/Cas9を用いたゲノム編集技術
}

\section{遠藤 亮*1, 賀屋秀隆 $* 1$, 土岐精一 $* 1,2$}

*1 農業 - 食品産業技術総合研究機構生物機能利用研究部門, $* 2$ 横浜市立大学木原生物学研究所植物分子育種科学部門

ゲノム編集技術の進展は目覚ましく, 人工制限醰素を 用いて標的遺伝子を破壊することは多くの生物種で一般 的な技術となりつつある。 そこで現在は標的遺伝子を狙 いどおりに改変することが技術開発の目標となってい る. 現在最も沉用されている人工制限酵素ツールは CRISPR/Cas9 (Clustered Regularly Interspaced Palindromic Repeats/CRISPR-associated protein 9) システ ムである。このシステムに扔いて中心的役割を担うのが Cas9 タンパク質で, 通常Streptococcus pyogenes（化膿 連鎖球菌）由来のCas9（SpCas9）が用いられている. また $\mathrm{SpCas} 9$ 以外にもさまざまな細菌由来のCas 9 や Cas9類似の RNA 依存性 DNA エンドヌクレアーゼ Cpf1 (CRISPR from Prevotella and Francisella 1) も利用さ れ始めている. Cas9, Cpf1 などをゲノム編集に用いる際 の課題として, PAM (Protospacer Adjacent Motif) と 呼ばれる特定の塩基配列に隣接して標的配列を設定しな ければならないため, 標的配列の選択には制限があるこ と, オフターゲット活性（本来の標的以外の配列を切断 すること）があることが挙げられる。これらの課題を解 決する技術として, PAMによる標的配列制限を緩和す るCas9, オフターゲット活性を低下させたCas9など, 改良型Cas9が次々と開発されている。ささらに, CRISPR/Cas9を用いた標的配列に打ける塩基置換技術も開 発されている。

現在, 主要作物のほとんどにおいて SpCas9による遺
伝子破壊に成功しているが，新規Cas9や改良型Cas9 に よるゲノム編集技術は, その適用範囲を広げるととも に，文字ど㧍りゲノムの塩基配列を「編集」できる技術 となりつつある. 本稿では最近のCas9を用いたゲノム 編集技術の進展と, その作物への適用例について紹介し たい.

CRISPR/Cas9 は本来細菌の獲得免疫において機能す るシステムであり, Cas9はRNA 依存性 DNAエンドヌ クレアーゼをコードし，CRISPR 遺伝子座には過去に 感染したファージなどのゲノム配列の一部を含む crRNA（CRISPR RNA）が繰り返し配列として座上し ている(1). ファージが細菌に感染したとき，CRISPR 遺 伝子座から発現する crRNA は tracrRNA（trans-activating CRISPR RNA）と相互作用し guide RNA（gRNA） を形成，Cas9がgRNAに結合してRNA-タンパク質複 合体を形成する(1)。この複合体は，crRNAに含まれる 標的配列（Protospacer sequence）情報を基にファージ のゲノム上から相同な標的配列を探し切断することで免 疫機構の一部として機能する(1, 2). Cas9 複合体による標 的配列の切断は，まず標的配列に隣接したPAMがCas9 タンパク質により認識され，その次に隣接する標的配列 がCas9/gRNA複合体によって認識された後に起きる(3). Cas9はそれぞれ固有のPAMを認識する。たとえば, SpCas9, SaCas9はそれぞれ標的配列に隣接したNGG (N: A or C or G or T), NNGRRT (R: A or G) という 


\section{$\bowtie$ ラム $\bowtie$}

\section{文字通りのゲノム編集}

「ゲノム編集」。しかし，現在の技術では，「真のゲ ノム編集」ではない。「編集」を新明解国語辞典（第 6版）で引いてみると，「いったん入力したプログラ ムやデータの一部を削除したり, 並べ替えたり, さら には新たに追加したりして手直しすること」とある。 これまでのゲノム編集技術のほとんどは，遺伝子を 破壊することで,「編集」という意味からはすこし距 離がある。実際，CRISPR/Cas9システムによって標 的配列が切断された後に誘導される変異のスペクト ラムは制御できず，欠失や扱入される塩基の数，どの 塩基がどの塩基に置換されるのか, 予測できない。 また, CRISPR/Cas9 は切断部位の近傍にCas9が最初 に認識する配列であるPAM配列という数塩基の配列 が必要であり，そのことが自由な切断部位の選択を妨 げている。 したがって標的遺伝子を破壊することは できても，標的遺伝子の標的配列を意眓するように 改変することは困難である.
そこで現在, 構造科学, タンパク質工学, さらに は今年度のノーベル化学賞の対象になった進化分子 工学を駆使して, Cas9やCas9 と類似の機能をもつ酵 素を改変し，任意の配列を正確に認識でき，望み通 りの塩基配列に書き換える「真のゲノム編集酵素」の 開発が厳しい競争のもとで行われている。

一方，次から次へと新たな改良が為されたゲノム 編集酵素が発表される中で，どのバージョンを使う べきか, 研究ツールとしてこの技術を利用する研究 者は悩んでいる。この状況はスマートフォンの開発 と利用者の関係に良く似ている。一方，現在のCRISPR/Cas9はスマートフォンではiPhoneの様な立ち位 置にあるが，Cas9 は比較的大きなタンパク質で，デ リバリーや今後の新たな機能付加を考えると, 大幅 な小型化が望まれる. CRISPR/Cas9はノーベル賞を 確実に取れる技術だと考えられているが，ゲノム編 集技術開発研究者としてはCRISPR/Cas9を基に改良 を続けていくべきか，もっと小型で機能付加しやす いゲノム編集酵素をゼロから開発し直すべきか，そ の両方から攻めるか, 戦略を決める時期が近付いて いるように思われる。
配列をPAMとして認識する(4,5)。そのため, PAMは, CRISPR/Cas9 システムによりゲノム編集を行う際に標 的配列選択の制限要因となる.

\section{gRNAの改良}

DoudnaらはCRISPR/Cas9 システムの最初の改良と して, crRNAと tracrRNAからなるgRNAを一体化し た single guide RNA（sgRNA）の開発に成功してい る(6). crRNA と tracrRNAを共発現させるには，同時 期・同組織で機能する $2 つ の$ 転写単位が必要になるが, sgRNAであれば一つの転写単位で効率的に発現させる ことができることから，現在はsgRNAがゲノム編集で 使われることが多い。これまでに gRNAについてさま ざまな工夫がなされている，Yinらは, enhanced sgRNA（e-sgRNA）を報告している。e-sgRNAは，本 来の tracrRNA 領域にある複数の塩基をメチル化（2'-Oメチルリボヌクレオチド）あるいはフルオロ化（2'-フル オロリボヌクレオチド）したsgRNAを作成した ${ }^{(7)}$ 。こ れらの修飾はsgRNA と SpCas9 との相互作用に影響す ることなく，ゲノム編集活性を向上させる，人工核酸で ある locked nucleic acids（LNA）はRNAやDNAに対 する結合親和性を上昇させることから，Cromwell らは crRNAにLNAを導入し，オフターゲット活性を抑制で
きることを報告している( ${ }^{(8)}$.

\section{多様な Cas9}

現在，さまざまな細菌からCas9が単離され，その特 徵が精力的に解析されている. Cas9に類似した機能を もつCpf1（Cas12a）も単離されゲノム編集に応用され ている. Cas9 と Cpf1はそれぞれクラス 2 に分類され, 各々はさらに異なるサブタイプに分類される(9). クラス 2 に属するものは，単一サブユニットで機能する( ${ }^{(9)}$ 。こ れらのCas9, Cas9様ヌクレアーゼはタンパク質の大き さや認識する PAM, DNA 切断末端の形状に違いをもつ ことから，標的配列の選択性の増加と多様な変異パター ンを生み出すことが可能になると考えられる．代表的な Cas9およびCpf1（Cas12a）を表1に示し，以下にそれ ぞれの特徴について触れたい。

\section{SpCas9}

Streptococcus pyogenes（化膿連鎖球菌）由来の $\mathrm{SpCas} 9$ は1368アミノ酸残基からなり, type II-Aに分類され, ゲノム編集のツールとして最初に使用されたことから現 在最も広く使用されている(6). 立体構造解析から, SpCas9は2つのローブ（RECローブとNUCローブ）に よって構成され（図1A)，RECローブはgRNAと標的 
表 1日さまざまなCas9 とCpf1

\begin{tabular}{|c|c|c|c|c|c|c|}
\hline 名前 & 由来 & タイプ分類 & アミノ酸残基数 & 切断DNA末端形状 & PAM 配列 & 文献 \\
\hline SpCas9 & Streptococcus pyogenes & II-A & 1,368 & 平滑 & NGG & Nishimasu et al. (2014) \\
\hline SaCas9 & Staphylococcus aureus & II-A & 1,053 & 平滑 & NNGRRT & Nishimasu et al. (2015) \\
\hline FnCas9 & Francisella novicida & II-B & 1,629 & 平滑 & NGG & Hirano et al. (2016a) \\
\hline CjCas9 & Campylobacter jejuni & II-C & 984 & 平滑 & $\begin{array}{l}\text { NNNNACAC } \\
\text { NNNVRYM }\end{array}$ & $\begin{array}{l}\text { Yamada } \text { et al. (2017) } \\
\text { Kim et al. (2017a) }\end{array}$ \\
\hline NmCas9 & Neisseria meningitidis & II-C & 1,082 & 平滑 & NNNNGATT & Hou et al. (2013) \\
\hline FnCpfl & Francisella novicida & $\mathrm{V}-\mathrm{A}$ & 1,300 & $5^{\prime}$ 突出 & TTN & Zetsche et al. (2015) \\
\hline AsCpf1 & Acidaminococcus sp. & $\mathrm{V}-\mathrm{A}$ & 1,307 & $5^{\prime}$ 突出 & TTTN & Zetsche et al. (2015) \\
\hline LbCpf1 & Lachnospiraceae bacterium & $\mathrm{V}-\mathrm{A}$ & 1,231 & $5^{\prime}$ 突出 & TTTN & Zetsche et al. (2015) \\
\hline
\end{tabular}

A

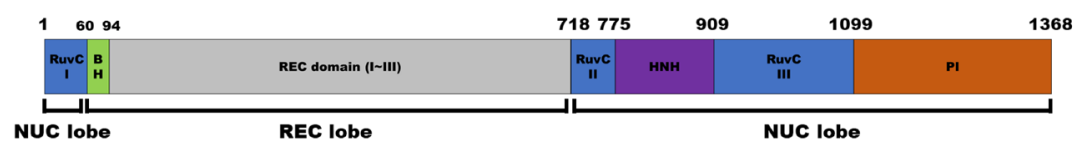

B

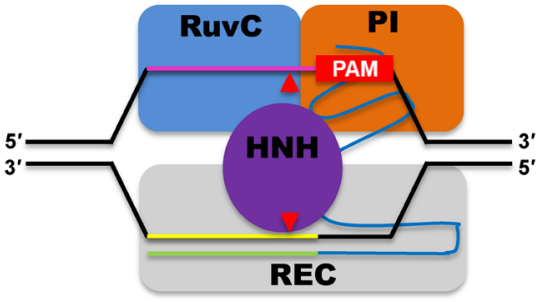

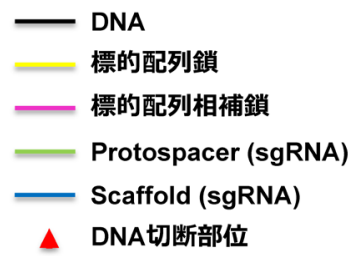

Nishimasu et al., 2015より改変
図 1・SpCas9の二次構造と三次構造

A: SpCas9ポリペプチドの二次構造. 上部の 数字は各ドメインの境界の位置を示す. REC lobe: BH, Recドメインによって構成される機 能単位. NUC lobe: HNH, Ruv, PI (PAM-interacting）ドメインによって構成される機能 単位. B: SpCas9 と sgRAおよびDNAの複 合体, 三次構造イメージ.
DNA 鎖の認識に機能し，NUCローブは標的DNA 鎖の相 補鎖とPAMの認識および二本鎖 DNA 切断に働くことが わかっている (4) (図 1B). SpCas9の標的配列長は約 20 塩 基で, PAMとしてNGGを認識し, 切断活性も高い. SpCas9による変異パターンは, 数塩基の欠損, 挿入が多 い.イネにおいては, 2 力所の切断により $245 \mathrm{~kb}$ 欠損の 報告もある ${ }^{(10)}$. 一方, 塩基置換変異の頻度は極めて低 い. SpCas9のオフターゲット活性は標的配列と相同性の 高い配列に変異を入れる可能性がある。オフターゲット 活性は相同性の高い遺伝子間での多重遺伝子破壊の場合 は役立つが(11)，標的遺伝子のみの改変を希望する場合 は, オフターゲット活性を抑制したい. そこでオフター ゲット活性を抑制するためのさまざまな改良が精力的に おこなわれている。その一つは, SpCas9-HF1 (high fidelity variant)である(12). Kleinstiverらは, SpCas9-gRNA 複合体とDNAのRECローブにおける非特異的な相互作 用が強いことでオフターゲット活性が高くなると考え, 立体構造に基づき標的配列と非特異的に水素結合を形成 する4つのアミノ酸（N497, R661, Q695, Q926）をアラニ ン（A）に置換し，そのオフターゲット活性を評価した.
同4アミノ酸置換をもつ SpCas9-HF1の変異導入活性は, 野生型のSpCas9の $85 \%$ 以上を維持しつつ, オフター ゲット活性を減少させた。ささらにHF1の4アミノ酸置換 にさらに1アミノ酸置換を加えた HF2（HF1+D1135E), HF3 (HF1+L169A)，もしくはHF4（HF1+Y450A）の 活性を評価したところ, 標的変異導入活性（オンター ゲット活性）がやや低下するものの，オフターゲット活 性は著しく低下していた(12)。同様のアイデアで, SpCas9-HF1 と異なる変異をNUCローブに導入することで オフターゲット活性を抑制したのが eSpCas9（enhanced specificity SpCas9) である(13). Slaymakerらは，2つの タイプの eSpCas9（1.0）と（1.1）を報告した. 1.0は, K810A, K1003A, R1060Aの3箇所, 1.1は, K848A, K1003A, R1060Aの3箇所に変異を導入したものである. SpCas9$\mathrm{HF} 1$ と eSpCas9の標的変異導入活性は，野生型とほぼ同 程度であるが, どちらが優れているのであろうか. Zhangらはイネにおいて, 同一gRNAを用いて比較した ところ, SpCas9-HF1, eSpCas9 ともに同程度の標的変異 導入活性をもち，オフターゲット活性も両者に明確な差 は認められなかった ${ }^{(14)}$.一方, SpCas9-HF1 と eSpCas9 
（1.1）の変異を併せ持つHeFSpCas9s（"Highly enhanced Fidelity” SpCas9 variants）は，よりオフターゲット活性 を抑制できるという報告もある ${ }^{(15)}$. Chen らは, SpCas9$\mathrm{HF} 1$ と eSpCas9（1.1）を比較しつつ，新たな変異 （N692A/M694A/Q695A/H698A）を導入したHypaCas9 (hyper-accurate Cas9 variant) について報告しており， HypaCas9は標的変異導入活性を維持しつつ, SpCas9$\mathrm{HF} 1$ と eSpCas9（1.1）よりもさらにオフターゲット活性 を抑制できることが示されている ${ }^{(16)}$. またCasini らは酵 母を用いた指向性進化による選抜法（特定の目標に向け て進化させる方法）により RECドメインに4つの変異 （M495V/Y515N/K526E/R661Q）をもつ evolved Cas9 （evoCas9）を開発し，SpCas9-HF1およびeSpCas9（1.1） よりもオフターゲット活性が低下していることを報告し ている(17).

\section{SaCas9}

Staphylococcus aureus（黄色ブドウ球菌）由来の SaCas9は, 1053アミノ酸残基からなり, 比較的小さい Cas9である ${ }^{(18)}$. SaCas9は, SpCas9 と同じくtype II-A に分類される。標的配列長は, 21〜23塩基で SpCas9 りも少し長い(18)。植物に打いて Cas 9 遺伝子を過剩発現 させた場合, SaCas9 の変異導入活性はSpCas9に引けを とらない(19). PAMはNNGRRT (R: A or G) であるが, $\mathrm{PAM}$ の 6 番目の Tについては塩基特性が低いという報 告もある ${ }^{(18,19)}$. 植物では Tがあるほうが変異導入効率 は高い(19). Kleinstiverらは, SaCas9のPAM (認識)の 制限を緩和するために3つの変異 (E782K/N968K/ $\mathrm{R} 1015 \mathrm{H})$ を導入した KKH SaCas9を作成した. KKH SaCas9は，NNNRRTをPAMとして認識することがで きる(20)。これにより，KKH SaCas9が認識できるPAM の出現頻度は $1 / 16$ となり, SpCas9のそれと同じにな る. SaCas9 は二分割しても活性を維持している( ${ }^{(5)}$. SaCas9を2つに分割することで発現コンストラクトの 小型化が可能となり，植物ウイルス vectorから二分割 したSaCas9（split-SaCas9）とsgRNAを発現させるゲ ノム編集にも成功している ${ }^{(21)}$ 。この技術を発展させる ことで, 植物ゲノムに外来遺伝子を組み込ませることな くゲノム編集ができると期待される．またごく最近, 植 物に扔いて，SaCas9の新たな活用方法として, SaCas9 とSpCas9 の nickaseを共発現させることで, 効率的に 標的組換え (gene targeting) ができるという興味深い 報告がある(22).

\section{FnCas9}

Francisella novicida 由来のCas9. FnCas9は, SpCas9 よりも大きく 1629 アミノ酸残基からなる ${ }^{(23,24)}$. FnCas9 はII-Bに分類され，このカテゴリーにあるCas9は，サ イズが大きいという特徵がある. FnCas9のPAMは, NGGである。平野らは, タンパク質立体構造に基づき, FnCas9に3つの変異（E1369R/E1449H/R1556A）を導 入したFnCas9 の RHA variantを作成した ${ }^{(24)}$. この variant は，YGをPAMとして認識することができる。これ までのところ，植物において FnCas9を用いたゲノム編 集についての報告はない.

\section{CjCas9}

Campylobacter jejuni 由来のCas9で, 984アミノ酸か ら成り，報告のあるCas9の中でも小さいCas9である (25). CjCas9はType II-Cに分類される. Type II Cに属 するCas9は, Type II Aに属するCas9よりも DNA helicase活性が弱いとされている(26). CjCas9のPAMにつ いては2つの報告があり, 一つはNNNVRYM（V: A or C or G, R: A or G, Y: C or T, M: A or C) ${ }^{(27)}$, 他方は NNNNACAC C(28)である。前者のPAMの出現頻度は $3 / 32$ に対して，後者は $1 / 256 て ゙ あ る 。$ 標的配列長は 22-20塩基. CjCas9により誘導される変異パターンは, 挿入・欠失変異である. 小さいという CjCas9 の特徵を 活かしてAAV (Adeno Associated Virus：アデノ随伴 ウイルス）にCjCas9を搭載し，ゲノム編集できること が報告されている(28). さらに, CjCas9 は, 動物培養細 胞において, SpCas9あるいは SaCas9 と同程度のゲノム 編集活性があるとされている(28). 最近, CjCas9は，内 在の mRNAsを切断することが報告されている(29). 今 後, CjCas9は, RNA editingにおいて利用される可能 性がある。これまでのところ，植物においてCjCas9を 用いたゲノム編集についての報告はない.

\section{NmCas9}

Neisseria meningitidis 由来のCas9で, $1082 ア ミ ノ$ 酸 から成り, CjCas9 とおなじく type II-Cに分類される. NmCas9のPAMは，NNNNGATTである ${ }^{(30)}$. 標的配列 長は22-24塩基 ${ }^{(31)}$. NmCas9によって導入される変異パ ターンは, 挿入・欠失変異である. anti-NmCas9による 活性制御が可能である ${ }^{(32)}$. またCjCas9 と同じく, RNA を切断する活性をもつ ${ }^{(33)}$. これまでのところ, 植物に おいてCjCas9 と同じく NmCas9を用いたゲノム編集に ついての報告はない. 


\section{Cpfl (Cas12a)}

Cas9 と同様に機能するが，異なる特徴をもつ RNA 依 存性エンドヌクレアーゼCpf1（最近はCas12a と呼ばれ ることがふえている）が報告されている(34)。これまで にゲノム編集に応用されているAsCpf1, LbCpf1 および FnCpf1の特徵について表1にまとめた。これらCpf1は Cas9 と同様にクラス 2 に分類されるが, type V-Aに分 類され (表1), Cas9 と異なる特徵が4つある ${ }^{(34)}$.一つ 目の相違はCas9のPAMは標的DNA 配列の下流に位置 するのに対し，Cpf1のPAMは標的DNA 配列の上流に 隣接している点である. 2 つ目の相違はCas9が二分子の RNA（crRNA と tracrRNA）を必要とするのに対し， Cpf1 はcrRNA しか必要としない点である. 3つ目の相 違はCas9が標的配列内のPAM近傍を切断し平滑末端 を生じるのに対して，Cpf1 は標的配列内のPAMから 20 塩基程離れた部位を切断し $5^{\prime}$ 突出末端を生じる点, 4 つ 目の相違はCas9がグアニンに富むPAMを認識するが, Cpf1 はチミンに富むPAMを認識する点である（表1）。 Zetsche らの報告では AsCpf1 と LbCpf1 の哺乳類細胞に おけるゲノム編集効率が高く, FnCpf1 は同効率が低い という結果が示されていたが，現在では FnCp1による 植物, 酵母, ヒト細胞でのゲノム編集例が報告されてい る ${ }^{(35}$-37). 標的 DNA 配列を選ぶ場合, 候補配列の出現率 はPAMの長さに依存して制約を受ける。したがって最 も PAMが短い FnCpf1の有用性が高いと考えられるが, FnCpf1の最適なPAMはTTNではなくVTTV, KYTV またはTTTVであるという報告もあり，明確になって いない(36 38). AsCpf1 と LbCpf1のオフターゲット活性 は低く, SpCas9-HFと同等であると報告されている. また LbCpf1 およびAsCpf1の立体構造解析から，Cpf1 の二次配列上のドメイン構成がCas9のそれとは異なる ことがわかっている ${ }^{(39,40)}$. AsCpf1 の立体構造情報を基 にPAM-interactingドメインに2点変異 (S542R/ K607R）もしくは3点変異 (S542R/K548V/N552R）を 導入することにより認識するPAMを TYCVもしくは TATVに改変し, LbCpf1に扔いて上記と同様の変異を 導入することで, PAM認識を同様に改変することに成 功している ${ }^{(41,42)}$. Cpf1により導入される変異のほとん どは欠失であり，一塩基挿も高頻度で生じる Cas9 の 変異パターンとは異なっている.これはDNA切断後に 形成される末端形状の違いに起因すると考えられ, Cpf1 と同様，突出末端を形成する Zinc finger nucleases (ZFNs) やTALENs (Transcription activator-like effector nucleases）などによる変異パターンも欠失であるこ とから，突出末端が生じる DNA二重鎖切断に特異的な
DNA 修復系が塩基欠失という変異作出に寄与している と考えられる(43).

先に述べたCpf1のCas9 とは異なる性質を用いて効率 的な標的組換えやノックインができるのではないかと考 えられる。Cpf1はPAMから 20 塩基程離れた部位（正 確に認識されるシード配列の外側）を切断するのに対 し，Cas9はPAMから 3 塩基離れた部位（シード配列内 部）を切断するため, Cas9 は切断部位に一度変異が入 れば2度切りが不可能であるが, Cpf1 は切断後変異が導 入されても再度切断できることが知られている(34). こ の性質は，標的組換えの際は有利だという報告があ る(44). 一方，これまで標的組換えやノックインには相 同組換えによるDNA 修復系が利用され, 同修復には $3^{\prime}$ 突出構造の形成が重要であることが知られているが, 相 同性に依存しない正確なNHEJを利用したノックインが 平滑末端を作るCas9を使って報告されて抢り ${ }^{(45)}$, 突出 末端を作るCpf1を用いて同様の実験を行えば，さらに 効率の良いノックインが可能だと期待される.

\section{7. 塩基置換型Cas9}

SpCas9により導入される変異パターンは, 挿入・欠 失がほとんどである。ゆえに，標的遺伝子を破壊する目 的においてはSpCas9など，切断効率の高い人工制限酵 素そのものを利用することが多い. しかし，酵素活性や タンパク質間相互作用の調節，標的遺伝子の活性制御と いう目的には，塩基置換が効果的（有効）な場合が多い ため, 標的部位に塩基置換変異のみを導入する技術開発 も精力的に進められている.

二本鎖DNA 切断活性を消失させた nickase Cas9 ある いはdead Cas9に脱アミノ化酵素であるデアミナーゼを 融合することで，標的位置に挿入あるいは久失変異を生 じさせずに，塩基置換変異をのみを導入することを狙っ た塩基置換型Cas9が開発されている。この場合, Cas9 は標的部位へデアミナーゼを誘導する役割を果たしてい る、最初に報告されたのがシトシンからチミンへの塩基 置換変異を起こす塩基置換型Cas9である ${ }^{(46,47)}$. シトシ ンの脱アミノ化酵素ファミリーには, AID (Activation induced deaminase) と APOBEC (Apolipoprotein B mRNA-editing enzyme catalytic polypeptide-like) があ る ${ }^{(46,47)}$. シトシンは脱アミノ化されるとウラシルに置 換され, ウラシルは, ポリメラーゼにより, 最終的に, チミンに置き換えられる，西田らは，ウミヤツメ由来の AIDオルソログであるPmCDA1 (Petromyzon marinus cytosine deaminase 1) と nickase SpCas9（D10A） あ るいはdead SpCas9（D10A/H840A）を融合させた 
Target-AIDを用いて，酵母に打いて効率的にシトシン （C）からチミン（T）への塩基置換変異を導入できるこ とを示した ${ }^{(47)}$. 島谷らは, トマト・イネにおいてもこ の Target-AIDにより標的遺伝子座に塩基置換変異が導 入できることを示した(48). 一方, Komorらは, ラット の APOBEC1 と nickase SpCas9 (D10A) さらにウラシ ル DNAグリコシラーゼ阻害タンパク質 (UGI: uracilDNA glycosylase inhibitor protein) を融合させたBE3 (Base Editor 3) を作成した. ウラシル DNAグリコシ ラーゼは, 脱プリン脱ピリミジン部位エンドヌクレアー ゼとともに， ウラシルを除去修復しCに戻す。UGIは, この修復反応を阻害することで, APOBEC1による塩基 置換変異効率を上昇させることができる ${ }^{(46)}$. このBE3 を用いることで, 標的遺伝子座に効率的にCから $\mathrm{T} へ の$ 塩基置換変異を導入できることを示した ${ }^{(46)}$. イネ・コ ムギにおいても APOBEC1-nickase SpCas9（D10A）に より効率的に塩基置換変異が導入されることが示されて いる(49). PmCDA1を用いる Target-AIDと rat APO$\mathrm{BECl}$ を用いる $\mathrm{BEs}$ では, 双方とも Cから $\mathrm{T} へ の$ 塩基置 換変異が抢こるが, Target-AIDでは, PAMから上流 18 塩基周辺の 5 塩基にあるシトシンが標的となり, BEs ではPAMの上流 15 塩基を中心に 5 塩基周辺のシトシン が標的となる ${ }^{(46,47)}$. また APOBEC1にアミノ酸置換を 導入することにより, 変異導入の幅を 5 塩基からに 2 塩 基に狭めることもできる(50). これらの違いを利用すれ ば，同じ標的配列で異なる位置に塩基置換変異を導入す ることができる. Komorらは塩基置換変異導入時に起 きる挿入久失変異率を低下させるため, UGI 2 個付加 した BE4を作成し同変異率を減少させることに成功し た。また，BE4に加え，ファージ Mu由来の二本鎖 DNA 末端を分解から守るGumタンパク質を付加するこ とで, さらに挿入久失変異率が低減することを示してい る ${ }^{(51)}$. また標的配列への APOBEC1誘導タンパク質と して, SpCas9 以外にも SaCas9 P LbCpf1 の利用につい ても報告されている(51, 52).

$\mathrm{C}$ から $\mathrm{T}$ への塩基置換に加え，アデニン（A）からグ アニン $(\mathrm{G})$ への塩基置換についても報告されている. Gaudelliらは, adenine base editors (ABEs) によりA を効率的に Gに置換できることを示した ${ }^{(53)}$. アデニン は, 脱アミノ化酵素によりイノシンに置換される，イノ シンは, DNAポリメラーゼによってグアニンとして認 識され, 結果グアニンに置換される。ところが, DNA のアデニンの脱アミノ化酵素は見いだされていなかっ た. そこで, Gaudelliらは, tRNAのアデノシンデアミ ナーゼ（TadA）を改変し, nickase Cas9 と融合させる
ことで，効率的にアデニンをグアニンに塩基置換する変 異が導入できることを，ヒト培養細胞を用いて明らかに した. ABEsはごく最近, イネ,コムギ, シロイヌナズ

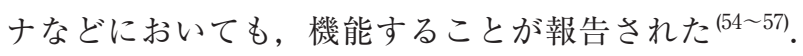
Traget-AIDあるいはAPOBEC1に，このABEsが加 わったことで, 12 通りある塩基置換変異パターンのう ち, 4つのパターン $(\mathrm{C} / \mathrm{G}$ から $\mathrm{T} / \mathrm{A}$ と $\mathrm{A} / \mathrm{T}$ か $\mathrm{G} / \mathrm{C})$ が可能となった。

\section{PAM 改変型Cas9}

これまでに標的配列の選択の幅を広げるという目的 で, PAM 認識配列を改変した SpCas9がいくつか報告 されている. KleinstiverらはPAM認識が弱まれば，必 要とされるPAMが単純化されるという発想の下，指向 性進化的手法によりアミノ酸置換 VQR (D1135V/ R1335Q/T1337R), EQR (D1135E/R1335Q/T1337R) およびVRER（D1135V/G1218R/R1335E/T1337R）に よりPAM認識配列がそれぞれNGAN, NGAG㧍よび NGCGに改変できることを明らかにした ${ }^{(58)}$.また，こ れらのアミノ酸置換はPAM-interacting ドメインに生じ ており (図 1), 立体構造解析によって同アミノ酸置換 のPAM認識に与える影響が明らかにされた ${ }^{(59,60)}$. 一 方, ごく最近, NGをPAMとして認識できる改変型 Cas9が報告された ${ }^{(61)}$.これにより, 塩基配列上にグア ニン1文字があれば，その上流を標的配列とすることが 可能となった. Huらは, Phage-Associated continuous Evolution（PACE: ファージによる連続分子進化法）を SpCas9に適応し，NG，GAA, GATをPAMとして認識 できるxCas9を作出した ${ }^{(61)}$. xCas9 3.7 は, SpCas9に対 して7箇所の変異 (A262T/R324L/S409I/E480K/E543D/ M694I/E1219V）をもち，ヒト培養細胞において標的配 列に変異導入活性をもつだけでなく, xCas9 と base editor architecture (BE3) ${ }^{(46)}$ あるいは $\mathrm{ABE}^{(53)}$ を融合させ ることで, 標的配列にあるシトシンをチミンにあるいは アデニンからグアニンに塩基置換できることも示してい る ${ }^{(61)}$. 興味深いことに, PAMを単純化させる変異の多 くは主に標的鎖の認識に関与するRECローブに位置し ており(図1A), これらの変異がどのようにしてPAM 認識に影響を及ぼしているのか興味深い。一方，NGを $\mathrm{PAM}$ として認識できるSpCas9-NG を西増らが立体構造 に基づき開発しており, xCas9 とは全く異なる変異で, 変異箇所はPAM-interacting ドメイン上にあり, PAM 認識を変化させている ${ }^{(62)}$. SpCas9-NGはヒト培養細胞 においてNGをPAMとする標的配列に変異導入活性が 確認されており ${ }^{(62)}$, さらにイネ・シロイヌナズナにお 
いても同様に変異導入活性をもつことがわかっている (Endo ら, Nature plants, in press).

\section{将来の展望}

Cas9の応用によりゲノム編集技術による遺伝子改変 に選択肢が増えてきている。ささまざまなCas9, Cpf1およ びPAM改変型Cas9の利用により，標的部位への欠失 挿入変異の導入だけでなく, 塩基置換型 Cas9 による塩 基置換変異も導入可能となってきた（図2）。これらの Cas9 は生物種に対応したコドンの最適化や核移行シグ ナルの数や位置などを変えることでさらに変異導入効率 を高めることができる(56, 63 65)．農業分野では放射線や 化合物を用いた突然変異育種は一般的であることから， 今後CRISPR/Cas9などのゲノム編集システムについて の一般の方の理解が進むことにより，CRISPR/Cas9を 用いた植物育種は世界レベルで急速に進展すると考えら れる。一方, 作物の変異育種において有用形質が標的遺
伝子破壊による機能欠失変異により得られる場合と，特 定の塩基置換により生じる遺伝子発現の変化やアミノ酸 置換によるタンパク質の機能変化により得られる場合が 考えられる．現在の技術レベルでは機能欠失を誘導する 標的変異導入は可能であり, 塩基置換型Cas9 応用す れば，ある程度の希望する塩基置換は可能であるが，ど の場所にある，どの塩基でも自在に塩基置換できる技術 には至っていない。このような目的を成し得る技術とし ては，現状では，鋳型（Donor DNA）を用いる標的組 換え技術が適切であると考えられる。われわれの研究グ ループではイネにおいて標的相同組換えによる遺伝子改 変で必要な塩基だけを改変することに成功しているが, 低頻度で起きる相同組換えのイベントを濃縮する手法が イネ以外の作物では確立されて抢らず，一般的育種技術 の一つとして広まっていない $(66 \sim 69)$. 一方, 動植物にお いてCRISPR/Cas9により標的遺伝子座を切断すること で相同組換え効率を上昇させることが報告されてい る ${ }^{(68,70)}$. Cas9 によって誘導されたDNA 切断部位は主に

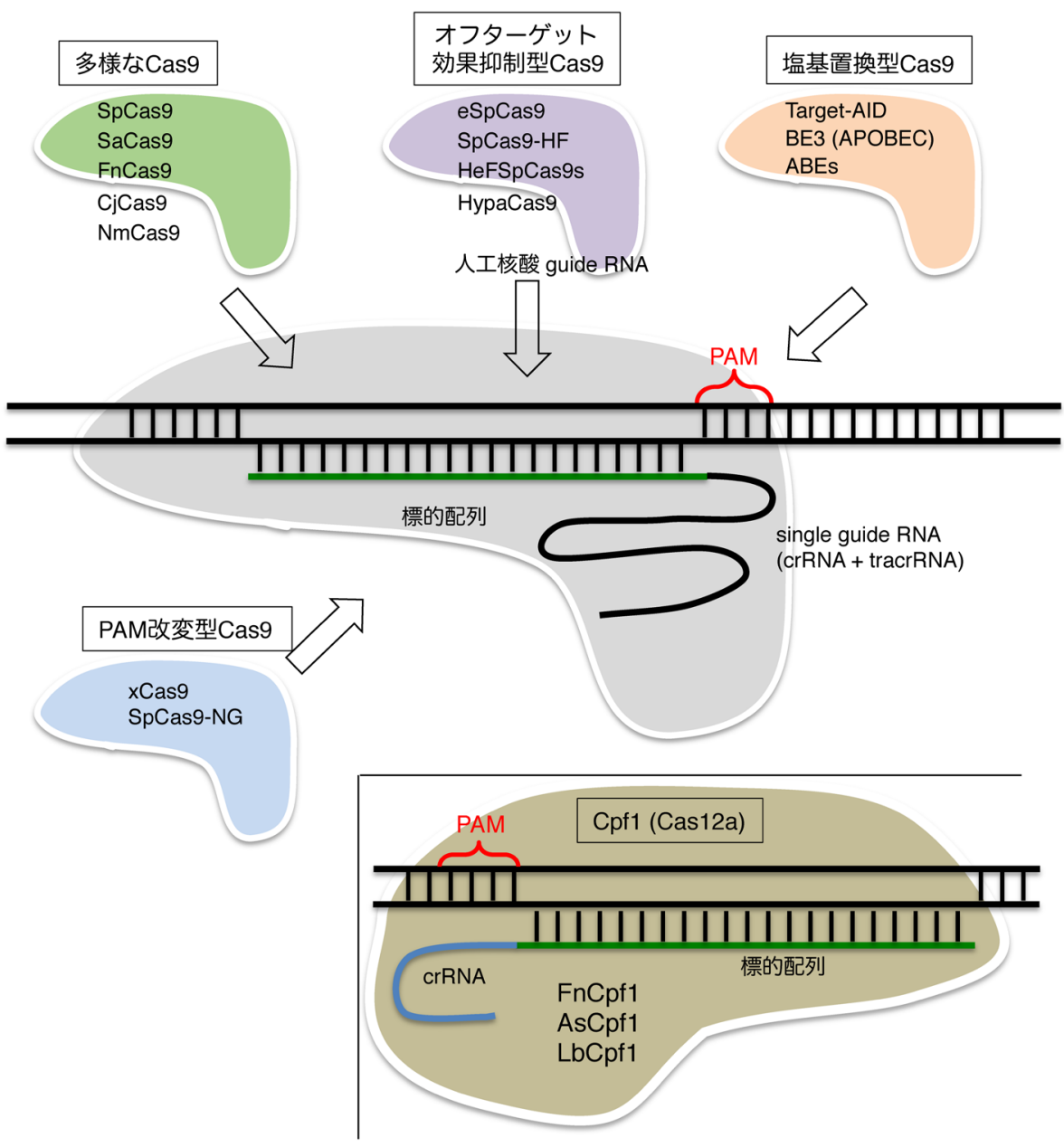

図 2 - Cas9 を中心とした多様なゲノム編集ツール 
2つの経路によって修復されることが知られており，そ れぞれ非相同末端結合 (Non-Homologous End Joining; NHEJ）と相同性依存的 DNA 修復（Homology Dependent Repair; HDR）と呼ばれる. NHEJは切断DNA末 端を直接結合させ，修復部位に扱入欠失変異が伴う場合 もあるが，HDRでは鋳型上の配列をコピー・ペースト することにより，標的遺伝子を正確に改変することがで きる. 最近, Cas9による標的部位の切断とともにNHEJ に関与するLig4に対する阻害剤を添加すると標的相同 組換え頻度が上昇することが多数報告されている ${ }^{(71 ~ 73)}$. NHEJ 関連分子の欠失した細胞ではHDR 頻度が上昇す ることから，NHEJによる修復機能の低下を補うため, HDRの頻度が上昇したと考えられる(74)。またHDRによ る修復時にはDNA 末端が 3 突出構造になる削り込みが 必要なことが知られているが, Cas9 nickasesを2つ組 み合わせたCas9 paired nickasesによる 3 突出構造の形 成により相同組換え効率が上昇することや (22,75,76), DNA 末端の削り込みに機能する CtIP をCas9 に融合すること で標的部位の相同組換え頻度が上昇することも示されて いる(77). 以上のような知見を植物に応用し標的組換え 技術が改良されれば，より高精度なゲノム編集も効率的 に行えるようになり，作物育種にかかる時間の短縮, 省 力化が行えるばかりでなく, 合成代謝経路の改変による 有用物質生産など，新たな育種が盛んになることと推測 される. 標的変異や標的組換えなどゲノム編集技術をさ らに高精度化することにより，狙った場所にだけ望みど おりの編集を加えることが可能となるため, 今後も医療 や農業分野を含む多くの産業にさらなるイノベーション を起こし続けると期待される。

文献

1) F. Jiang \& J. A. Doudna: Annu. Rev. Biophys., 46, 505 (2017).

2) R. Sapranauskas, G. Gasiunas, C. Fremaux, R. Barrangou, P. Horvath \& V. Siksnys: Nucleic Acids Res., 39, 9275 (2011).

3) S. H. Sternberg, B. LaFrance, M. Kaplan \& J. A. Doudna: Nature, 527, 110 (2015).

4) H. Nishimasu, F. A. Ran, P. D. Hsu, S. Konermann, S. I. Shehata, N. Dohmae, R. Ishitani, F. Zhang \& O. Nureki: Cell, 156, 935 (2014).

5) H. Nishimasu, L. Cong, W. X. Yan, F. A. Ran, B. Zetsche, Y. Li, A. Kurabayashi, R. Ishitani, F. Zhang \& O. Nureki: Cell, 162, 1113 (2015).

6) M. Jinek, K. Chylinski, I. Fonfara, M. Hauer, J. A. Doudna \& E. Charpentier: Science, 337, 816 (2012).

7) H. Yin, C. Q. Song, S. Suresh, Q. Wu, S. Walsh, L. H. Rhym, E. Mintzer, M. F. Bolukbasi, L. J. Zhu, K. Kauffman et al.: Nat. Biotechnol., 35, 1179 (2017).

8) C. R. Cromwell, K. Sung, J. Park, A. R. Krysler, J. Jovel,
S. K. Kim \& B. P. Hubbard: Nat. Commun., 9, 1448 (2018).

9) K. S. Makarova, Y. I. Wolf, O. S. Alkhnbashi, F. Costa, S. A. Shah, S. J. Saunders, R. Barrangou, S. J. J. Brouns, E. Charpentier, D. H. Haft et al.: Nat. Rev. Microbiol., 13, 722 (2015).

10) H. Zhou, B. Liu, D. P. Weeks, M. H. Spalding \& B. Yang: Nucleic Acids Res., 42, 10903 (2014).

11) M. Endo, M. Mikami \& S. Toki: Plant Cell Physiol., 56, 41 (2015).

12) B. P. Kleinstiver, V. Pattanayak, M. S. Prew, S. Q. Tsai, N. T. Nguyen, Z. Zheng \& J. K. Joung: Nature, 529, 490 (2016).

13) I. M. Slaymaker, L. Gao, B. Zetsche, D. A. Scott, W. X. Yan \& F. Zhang: Science, 351, 84 (2016).

14) D. Zhang, H. Zhang, T. Li, K. Chen, J. L. Qiu \& C. Gao: Genome Biol., 18, 191 (2017).

15) P. I. Kulcsar, A. Talas, K. Huszar, Z. Ligeti, E. Toth, N. Weinhardt, E. Fodor \& E. Welker: Genome Biol., 18, 190 (2017).

16) J. S. Chen, Y. S. Dagdas, B. P. Kleinstiver, M. M. Welch, A. A. Sousa, L. B. Harrington, S. H. Sternberg, J. K. Joung, A. Yildiz \& J. A. Doudna: Nature, 550, 407 (2017).

17) A. Casini, M. Olivieri, G. Petris, C. Montagna, G. Reginato, G. Maule, F. Lorenzin, D. Prandi, A. Romanel, F. Demichelis et al.: Nat. Biotechnol., 36, 265 (2018).

18) F. A. Ran, L. Cong, W. X. Yan, D. A. Scott, J. S. Gootenberg, A. J. Kriz, B. Zetsche, O. Shalem, X. Wu, K. S. Makarova et al.: Nature, 520, 186 (2015).

19) H. Kaya, M. Mikami, A. Endo, M. Endo \& S. Toki: Sci. Rep., 6, 26871 (2016).

20) B. P. Kleinstiver, M. S. Prew, S. Q. Tsai, N. T. Nguyen, V. V. Topkar, Z. Zheng \& J. K. Joung: Nat. Biotechnol., 33, 1293 (2015a).

21) H. Kaya, K. Ishibashi \& S. Toki: Plant Cell Physiol., 58, 643 (2017).

22) F. Wolter, J. Klemm \& H. Puchta: Plant J., 94, 735 (2018).

23) K. Chylinski, A. Le Rhun \& E. Charpentier: RNA Biol., 10, 726 (2013).

24) H. Hirano, J. S. Gootenberg, T. Horii, O. O. Abudayyeh, M. Kimura, P. D. Hsu, T. Nakane, R. Ishitani, I. Hatada, F. Zhang et al.: Cell, 164, 950 (2016a).

25) I. Fonfara, A. Le Rhun, K. Chylinski, K. S. Makarova, A.L. Lecrivain, J. Bzdrenga, E. V. Koonin \& E. Charpentier: Nucleic Acids Res., 42, 2577 (2014).

26) E. Ma, L. B. Harrington, M. R. O’ Connell, K. Zhou \& J. A. Doudna: Mol. Cell, 60, 398 (2015).

27) M. Yamada, Y. Watanabe, J. S. Gootenberg, H. Hirano, F. A. Ran, T. Nakane, R. Ishitani, F. Zhang, H. Nishimasu \& O. Nureki: Mol. Cell, 65, 1109 (2017).

28) E. Kim, T. Koo, S. W. Park, D. Kim, K. Kim, H. Y. Cho, D. W. Song, K. J. Lee, M. H. Jung, S. Kim et al.: Nat. Commun., 8, 14500 (2017a).

29) G. Dugar, R. T. Leenay, S. K. Eisenbart, T. Bischler, B. U. Aul, C. L. Beisel \& C. M. Sharma: Mol. Cell, 69, 893 (2018).

30) Z. Hou, Y. Zhang, N. E. Propson, S. E. Howden, L. F. Chu, E. J. Sontheimer \& J. A. Thomson: Proc. Natl. Acad. Sci. USA, 110, 15644 (2013).

31) C. M. Lee, T. J. Cradick \& G. Bao: Mol. Ther., 24, 645 (2016).

32) A. Pawluk, N. Amrani, Y. Zhang, B. Garcia, Y. Hidalgo- 
Reyes, J. Lee, A. Edraki, M. Shah, E. J. Sontheimer, K. L. Maxwell et al.: Cell, 167, 1829 (2016).

33) B. A. Rousseau, Z. Hou, M. J. Gramelspacher \& Y. Zhang: Mol. Cell, 69, 906 (2018).

34) B. Zetsche, J. S. Gootenberg, O. O. Abudayyeh, I. M. Slaymaker, K. S. Makarova, P. Essletzbichler, S. E. Volz, J. Joung, J. van der Oost, A. Regev et al.: Cell, 163, 759 (2015).

35) A. Endo, M. Masafumi, H. Kaya \& S. Toki: Sci. Rep., 6 , 38169 (2016a).

36) M. A. Swiat, S. Dashko, M. den Ridder, M. Wijsman, J. van der Oost, J. M. Daran \& P. Daran-Lapujade: Nucleic Acids Res., 45, 12585 (2017).

37) M. Tu, L. Lin, Y. Cheng, X. He, H. Sun, H. Xie, J. Fu, C. Liu, J. Li, D. Chen et al.: Nucleic Acids Res., 45, 11295 (2017).

38) Z. Zhong, Y. Zhang, Q. You, X. Tang, Q. Ren, S. Liu, L. Yang, Y. Wang, X. Liu, B. Liu et al.: Mol. Plant, 11, 999 (2018).

39) D. Dong, K. Ren, X. Qiu, J. Zheng, M. Guo, X. Guan, H. Liu, N. Li, B. Zhang, D. Yang et al.: Nature, 532, 522 (2016).

40) T. Yamano, H. Nishimasu, B. Zetsche, H. Hirano, I. M. Slaymaker, Y. Li, I. Fedorova, T. Nakane, K. S. Makarova, E. V. Koonin et al.: Cell, 165, 949 (2016).

41) L. Gao, D. B. T. Cox, W. X. Yan, J. C. Manteiga, M. W. Schneider, T. Yamano, H. Nishimasu, O. Nureki, N. Crosetto \& F. Zhang: Nat. Biotechnol., 35, 789 (2017).

42) T. Yamano, B. Zetsche, R. Ishitani, F. Zhang, H. Nishimasu \& O. Nureki: Mol. Cell, 67, 633 (2017).

43) Y. Kim, J. Kweon \& J.-S. Kim: (2013) TALENs and ZFNs are associated with different mutation signatures. In $\mathrm{Na}$ ture methods, pp. 185

44) M. A. Moreno-Mateos, J. P. Fernandez, R. Rouet, C. E. Vejnar, M. A. Lane, E. Mis, M. K. Khokha, J. A. Doudna \& A. J. Giraldez: Nat. Commun., 8, 2024 (2017).

45) K. Suzuki, Y. Tsunekawa, R. Hernandez-Benitez, J. Wu, J. Zhu, E. J. Kim, F. Hatanaka, M. Yamamoto, T. Araoka, Z. Li et al.: Nature, 540, 144 (2016).

46) A. C. Komor, Y. B. Kim, M. S. Packer, J. A. Zuris \& D. R. Liu: Nature, 533, 420 (2016).

47) K. Nishida, T. Arazoe, N. Yachie, S. Banno, M. Kakimoto, M. Tabata, M. Mochizuki, A. Miyabe, M. Araki, K. Y. Hara et al.: Science, 353, aaf8729 (2016).

48) Z. Shimatani, S. Kashojiya, M. Takayama, R. Terada, T. Arazoe, H. Ishii, H. Teramura, T. Yamamoto, H. Komatsu, K. Miura et al.: Nat. Biotechnol., 35, 441 (2017).

49) Y. Zong, Y. Wang, C. Li, R. Zhang, K. Chen, Y. Ran, J. L. Qiu, D. Wang \& C. Gao: Nat. Biotechnol., 35, 438 (2017).

50) Y. B. Kim, A. C. Komor, J. M. Levy, M. S. Packer, K. T. Zhao \& D. R. Liu: Nat. Biotechnol., 35, 371 (2017b).

51) A. C. Komor, K. T. Zhao, M. S. Packer, N. M. Gaudelli, A. L. Waterbury, L. W. Koblan, Y. B. Kim, A. H. Badran \& D. R. Liu: Sci. Adv., 3, 4774 (2017).

52) X. Li, Y. Wang, Y. Liu, B. Yang, X. Wang, J. Wei, Z. Lu, Y. Zhang, J. Wu, X. Huang et al.: Nat. Biotechnol., 36, 324 (2018b).

53) N. M. Gaudelli, A. C. Komor, H. A. Rees, M. S. Packer, A. H. Badran, D. I. Bryson \& D. R. Liu: Nature, 551, 464 (2017).

54) K. Hua, X. Tao, F. Yuan, D. Wang \& J. K. Zhu: Mol. Plant, 11, 627 (2018).
55) B. C. Kang, J. Y. Yun, S. T. Kim, Y. Shin, J. Ryu, M. Choi, J. W. Woo \& J. S. Kim: Nat. Plants, (2018).

56) C. Li, Y. Zong, Y. Wang, S. Jin, D. Zhang, Q. Song, R. Zhang \& C. Gao: Genome Biol., 19, 59 (2018a).

57) F. Yan, Y. Kuang, B. Ren, J. Wang, D. Zhang, H. Lin, B. Yang, X. Zhou \& H. Zhou: Mol. Plant, 11, 631 (2018).

58) B. P. Kleinstiver, M. S. Prew, S. Q. Tsai, V. V. Topkar, N. T. Nguyen, Z. Zheng, A. P. W. Gonzales, Z. Li, R. T. Peterson, J.R. J. Yeh et al.: Nature, 523, 481 (2015b).

59) C. Anders, K. Bargsten \& M. Jinek: Mol. Cell, 61, 895 (2016).

60) S. Hirano, H. Nishimasu, R. Ishitani \& O. Nureki: Mol. Cell, 61, 886 (2016b).

61) J. H. Hu, S. M. Miller, M. H. Geurts, W. Tang, L. Chen, N. Sun, C. M. Zeina, X. Gao, H. A. Rees, Z. Lin et al:: Nature, 556, 57 (2018).

62) Nishimasu H, Shi X, Ishiguro S, Gao L, Hirano S, Okazaki S, Noda T, Abudayyeh OO, Gootenberg JS, Mori H, Oura S, Holmes B, Tanaka M, Seki M, Hirano H, Aburatani H, Ishitani R, Ikawa M, Yachie N, Zhang F, Nureki O: Science, 361, 1259 (2018).

63) M. Mikami, S. Toki \& M. Endo: Plant Mol. Biol., 88, 561 (2015)

64) Y. Osakabe, T. Watanabe, S. S. Sugano, R. Ueta, R. Ishihara, K. Shinozaki \& K. Osakabe: Sci. Rep., 6, 26685 (2016).

65) M. P. Zafra, E. M. Schatoff, A. Katti, M. Foronda, M. Breinig, A. Y. Schweitzer, A. Simon, T. Han, S. Goswami, E. Montgomery et al.: Nat. Biotechnol., (2018).

66) A. Nishizawa-Yokoi, M. Endo, N. Ohtsuki, H. Saika \& S. Toki: Plant J., 81, 160 (2015a).

67) A. Nishizawa-Yokoi, S. Nonaka, K. Osakabe, H. Saika \& S. Toki: Plant Physiol., 169, 362 (2015b).

68) M. Endo, M. Mikami \& S. Toki: Plant Physiol., 170, 667 (2016b).

69) A. Nishizawa-Yokoi, H. Saika \& S. Toki: Methods Mol. Biol., 1469, 137 (2016).

70) D. Paquet, D. Kwart, A. Chen, A. Sproul, S. Jacob, S. Teo, K. M. Olsen, A. Gregg, S. Noggle \& M. Tessier-Lavigne: Nature, 533, 125 (2016).

71) V. T. Chu, T. Weber, B. Wefers, W. Wurst, S. Sander, K. Rajewsky \& R. Kuhn: Nat. Biotechnol., 33, 543 (2015).

72) T. Maruyama, S. K. Dougan, M. C. Truttmann, A. M. Bilate, J. R. Ingram \& H. L. Ploegh: Nat. Biotechnol., 33, 538 (2015).

73) G. Li, X. Zhang, C. Zhong, J. Mo, R. Quan, J. Yang, D. Liu, Z. Li, H. Yang \& Z. Wu: Sci. Rep., 7, 8943 (2017).

74) A. J. Pierce, P. Hu, M. Han, N. Ellis \& M. Jasin: Genes Dev., 15, 3237 (2001)

75) F. A. Ran, P. D. Hsu, C.-Y. Lin, J. S. Gootenberg, S. Konermann, A. E. Trevino, D. A. Scott, A. Inoue, S. Matoba, Y. Zhang et al.: Cell, 154, 1380 (2013).

76) S. Schiml, F. Fauser \& H. Puchta: Plant J., 80, 1139 (2014)

77) M. Charpentier, A. H. Y. Khedher, S. Menoret, A. Brion, K. Lamribet, E. Dardillac, C. Boix, L. Perrouault, L. Tesson, S. Geny et al.: Nat. Commun., 9, 1133 (2018). 
プロフィール

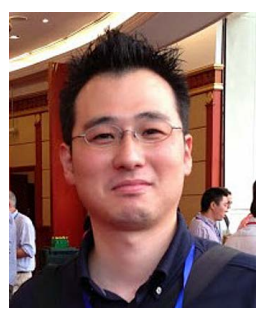

遠藤亮 (Akira ENDO)

$<$ 略歴 $>2006$ 年東京都立大学大学院理学 研究科生物科学専攻博士課程修了 $/ 2006$ 年理化学研究所博士研究員 $/ 2008$ 年オン タリオ州立トロント大学博士研究員 $/ 2012$ 年北海道農業研究センター特別研究員 2015年農業・食品産業技術総合研究機構 特別研究員 現在, 株式会社力亦力新規事 業開発部 $($ 企画) $<$ 研究テーマと抱負 $>$ ゲ ノム編集技術の作物への適用拡大 $<$ 趣味 $>$ ビール, 釣り

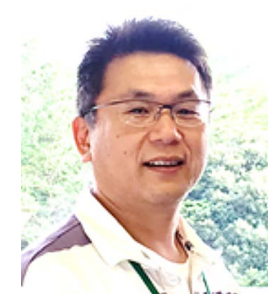

賀屋 秀隆 (Hidetaka KAYA)

<略歴>2001年京都大学大学院理学研究 科生物科学専攻博士後期課程修了／2001 年日本学術振興会特別研究員 $/ 2004$ 年東 京理科大学ゲノム創薬研究センターポスト ドクトラル研究員 $/ 2007$ 年同大学理工学 部応用生物科学科助教 / 2012 年東京大学 大学院理学研究科特別研究員 $/ 2014$ 年農 業生物資源研究所特別研究員 $/ 2016$ 年農 業・食品産業技術総合研究機構特別研究 員 $/ 2018$ 年愛媛大学大学院農学研究科准 教授 現在に至る<研究テーマと抱負 $>$ 相 橘のゲノム編集技術開発，シロイヌナズナ の形態形成と細胞メモリ<趣味>ぷらぷ ら, 読書

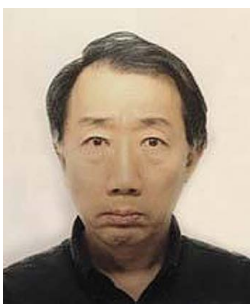

土岐 精一 (Seiichi TOKI)

<略歴>1989年東北大学大学院農学研究 科博士課程修了 / 1990 年北海道大学理学 部植物学科助手 / 1994 年農業生物資源研 究所主任研究官 $/ 2006$ 年同研究所ユニッ 卜長/2016年農業・食品産業技術総合研 究機構ユニット長, 2008年より横浜市立 大学木原生物学研究所客員教授 <研究テー マと抱負>ゲノム編集技術の開発とその植 物育種への適用 $<$ 趣味 $>$ 読書, 旅行, 釣り

Copyright (C) 2018 公益社団法人日本農芸化学会 DOI: 10.1271/kagakutoseibutsu.56.759 